Original Research Paper

\title{
The Effect of Stimulants on the Seed Germination and Growth of Schrenk's Spruce Seedlings
}

\author{
${ }^{1 *}$ Zhanera Adilbayeva, ${ }^{2}$ Bagila Maisupova, ${ }^{1}$ Kurmankul Abayeva, \\ ${ }^{1}$ Ainur Utebekova and ${ }^{2}$ Ruslan Akhmetov \\ ${ }^{1}$ Kazakh National Agrarian University, Almaty, Kazakhstan \\ ${ }^{2}$ Kazakh Scientific Research Institute of Forestry and Agroforestry Named After A.N. Bukeikhan, Almaty, Kazakhstan
}

\author{
Article history \\ Received: 13-11-2020 \\ Revised: 29-04-2021 \\ Accepted: 03-05-2021 \\ Corresponding Author: \\ Zhanera Adilbayeva \\ Kazakh National Agrarian \\ University, Almaty, \\ Kazakhstan \\ Email: zadilbayeva@list.ru
}

\begin{abstract}
Improving the agricultural technology of growing the planting material remains an urgent task and resolving it requires introducing modern scientific achievements in nursery production, such as the use of growth stimulants. Numerous studies have revealed a positive effect of growth stimulants on the seed germination and growth of seedlings of coniferous species. The study was aimed at studying the effects of stimulants and fungicides on the accelerated growth of Schrenk's spruce seedlings in protected and open soil. For the study, the Soldatsay forest nursery in the Talgar district of the Almaty region located on the lower part of the northern slope of the Trans-Ili Alatau was chosen. The methods of the research study included analyzing the information in the scientific literature about cultivating the planting material in greenhouse and nursery complexes and the use of modern growth regulators. In solving the tasks set, the common scientific methods were used, including the methods of experiment and analysis. The obtained data were processed using the methods of mathematical statistics. In this study, the authors used the following modern preparations of growth stimulators for Schrenk's spruce: Gumi-K, Phytobacirin and the Belarusian technology of growing in cassettes. For dosing, the authors used a Korean sprayer for coniferous trees Deltaspray. The authors conclude that all used preparations showed good efficiency in the pre-sowing treatment of the seeds, both in the open soil and in the greenhouse conditions. The use of complementary agricultural practices in the cultivation of spruce seedlings, including the root and foliar feeding of the seedlings with the Deltaspray solution, improves the quality of planting material, i.e., increases the weight of the above-ground part and improves its ratio to the weight of fine roots. With that, the period of growing standard spruce seedlings is reduced by one year.
\end{abstract}

Keywords: Forest Nursery, Greenhouse, Open Earth, Planting Material, Stimulant, Transfer

\section{Introduction}

The tasks of gradual transferring forestry management to continuous and sustainable forest management, increasing the productivity of forest stands and improving their qualitative composition have not lost their relevance today. One of the ways of solving them is artificial reforestation (Pentelkina, 2003). Its effectiveness is closely related to the quality of the planting material, i.e., its biological potential and physiological state, which determine the survival and growth rate of the plants, which, in turn, determine the productivity of future forest stands, their composition and sanitary condition. Therefore, it is important to improve agricultural techniques and increase the yield of the planting material per unit area with the help of modern techniques.

To satisfy the needs of the country's national economy in timber, it will be also necessary for the XXI century to create and cultivate highly productive economically valuable plants. Therefore, in order to quickly restore valuable conifers, it is necessary to develop effective lowcost technologies for growing the planting material (Chilimov et al., 1997). 
The technology of growing seedlings in a forest nursery is improved by including the new, or changing and refining the existing agricultural practices. In the entire process of growing coniferous seedlings in a forest nursery, agricultural practices are of paramount importance, which increases the soil germination of the seeds, the growth of intensity and the resistance of seedlings (Volkovich and Nosnikov, 2015).

In forestry management, a method has been introduced in recent decades, which has positively proven itself in the agriculture and experimental work at forest nurseries, namely, the method of growing the planting material with the use of growth stimulants (Novoseltseva and Smirnov, 1983; Rodin, 2002). Literature sources show two variants of using the growth stimulants: Seed treatment before sowing for accelerating seed germination and root fertilization of seedlings in the nursery for enhancing their growth (Nikolaeva et al., 1987; Ostroshenko, 2003; Rubtsov, 2009).

Foliar application, i.e., introducing the preparations by spraying them in an aqueous solution on the needles, is widely used among the modern plant care methods. Upon the introduction of the fertilizers to the roots, only $20 \%$ of the nutrients are used by the plants. At the same time, treating the needles using a foliar spray is much more effective and allows using up to $80 \%$ of the nutrients from the preparations. In the case of dense planting, such as in hedges, foliar nutrition is especially recommended (Lapa, 2011).

The methods of seeds pre-treatment are so multiple that it is often difficult to choose a particular one. The treatment of seeds and soil before planting with a preparation of a growth stimulant with fungicidal properties belongs to such methods of pre-sowing seed treatment.

The use of Kazakhstan stimulants like Phytobacirin and Gumi-K has been little studied, which determines the topic of the research study. The scientific novelty of this study lies in the fact that the effect of the above-mentioned growth stimulants on the seedlings of Schrenk's spruce has been studied for the first time, during the pre-sowing treatment of seeds and root and foliar application of nutrients during the vegetation season.

The preparation Phytobacirin has been developed based on a strain of cellulolytic bacteria and intended for the presowing treatment of plant seeds (Smirnova et al., 2012).

The preparation is based on the live cells of cellulolytic bacteria, which, due to their biological characteristics, can synthesize cellulose enzymes. This biological product has a complex effect; it improves the seed germination and stimulates further growth and development of the plants and thereby contributes to increasing the accumulation of the green mass during the entire vegetation period of the plants.

The mechanism of the strain action is based on the fact that seed treatment with bacteria causes a partial breakdown of the cellulose dense shell and replaces the process of scarification. This improves the transport of water and the mineral substances and nutrients dissolved in it to the endosperm and the seed germ. Besides, biologically active substances secreted by cellulolytic bacteria stimulate further development of the plants and increase their resistance to diseases. As a result, the germination and accumulation of green mass by the plants significantly increase.

Gumi-K is enriched with 11 important microelements and more than 80 natural elements and minerals, such as Selenium (Se), which increases the viability of plants in adverse conditions and extends the life of the plants; Nickel (Ni), which helps the plants to extract nitrogen from the soil and improves the soil microflora; Boron (B), which has an important function in the carbohydrate metabolism and promotes better use of calcium in the metabolic processes in plants; Zinc ( $\mathrm{Zn}$ ) and Cobalt (Co), which are required for normal fertilization of flowers and formation of fruits and seeds; they help plants fighting fungal and viral diseases and have a positive effect on the shelf life of fruits; Lithium (Li), which has a positive effect on the overall development of the plants (especially the root system), improves the transport of potassium and increases the resistance to diseases, including viral ones; Molybdenum (Mo), which regulates the accumulation of amino acids and protein, the formation of vitamins and stimulates the fixation of nitrogen from the air; Copper $(\mathrm{Cu})$, which increases the drought and frost resistance, the photosynthesis and the formation of enzymes; and sulfur (S), which helps form proteins. In the case of sulfur deficiency, respiratory processes are disturbed in plants and their resistance to diseases is deteriorated (Kan et al., 2017).

The microelements in the Gumi-K fertilizer are in the most biologically active polymer-chelated form and they are unmatched in terms of effectiveness in spraying plants. The optimal set of humic substances (the elixir of fertility) and microelements results in increased yields, improved quality and resistance to diseases. The new technology with a huge effect on humic substances allows obtaining economical and efficient nanogels (gel sols). Upon the ingress into an aquatic environment (soil, plants), they pass into nanoscale colloids that are natural for plants and protect them from stress: Frost, drought, chemical and radiation effects and damage by pests and diseases.

Potash humic substances, macroelements (nitrogen, phosphorus, potassium-1:1:3), 91 natural elements and minerals ensure powerful growth processes. They also increase the physiological activity (growth rate, development, processing of nutrients, resistance to diseases) (Titov and Kan, 2015).

The Belarusian technology (sowing in cassettes): Peat moss is used; it has favorable water and air conditions for the plants and is a good antiseptic. It contains many phenolic compounds and organic substances in the form of humic and fulvic acids, which act as plant growth stimulants. For growing coniferous annual seedlings, the 
height of the container should be at least $8-13 \mathrm{~cm}$ and the cell volume should be $110-250 \mathrm{~cm}^{3}$ (Babkov, 2013).

These cassettes have vertical slots and guide ribs in the walls of the cells, which ensure the most natural and proper development of the root system. The roots branch strongly and, reaching the cracks in the cell walls, receive "air treatment", which, in turn, contributes to the formation of active root tips that are ready to grow upon planting of the seedlings in the forest. The side slits also prevent the lack of oxygen in the peat lump in the cell and simultaneously serve as drainage in the case of excessive watering.

The Korean Deltaspray water-soluble fertilizer is intended for cultivating coniferous planting material and accelerating the growth of spruce.

In the experiments in Korea, Deltaspray is used for root and foliar additional fertilization by spraying. This preparation contains the following elements: Nitrogen, phosphorus and potassium 20-20-20 + 2MgO + trace elements (Maisupova et al., 2019b).

\section{Materials and Methods}

\section{Seed Preparation and Growth}

To increase the seed germination, to reduce the mortality from the lodging of the seedlings and to make the root system more fibrous, the seeds of Schrenk's spruce were stratified for two months (April to May). The stratification was required for preparing the seeds after a deep dormant period for sowing. Before the stratification, seeds of Schrenk's spruce had been soaked in water at room temperature for one day. The seeds extracted from the water were placed in cloth bags, after which the bags with the seeds were laid out on a platform with compacted snow and covered with a $60-80 \mathrm{~cm}$ thick layer of snow.

Before sowing, the bags with the seeds were taken from under the snow and treated in a $1 \%$ solution of potassium permanganate $\mathrm{KMnO}_{4}$ for $30 \mathrm{~min}$. After that, the seeds were kept for 1-2 $\mathrm{h}$ in the sun with stirring. After the stratification and before sowing, $300 \mathrm{~g}$ of quality class II seeds of Schrenk's spruce were treated with the following biologic preparations and biofertilizers for stimulating the plant growth: Phytobacirin, Gumi-K and separately using the cassette technology.

\section{Setting up Experiments on Sowing Schrenk's Spruce Seedlings}

In the greenhouse conditions, the experiments were made in four wooden boxes individually (1-control, 3experimental). Before sowing, all boxes had been filled with the soil taken from spruce forests, leveled out with a rake and large pieces of soil had been removed. After that, marks were made using a special wooden marker.
For the control, $300 \mathrm{~g}$ of quality class II seeds of Schrenk's spruce were sown following the scheme of 108-10-8-10 cm, i.e., with the width of $8 \mathrm{~cm}$ and the depth of $1 \mathrm{~cm}$. Following variant 1 (Phytobacirin), a suspension was prepared from $4 \mathrm{~mL}$ of phytobacirin and $320 \mathrm{~mL}$ of water. Two hundred grams of the spruce seeds were sprayed with the suspension and left for four hours in the shade. After that, they were sown into a wooden box following the scheme of $10-8-10-8-10 \mathrm{~cm}$. The width of the seeding rows was $8 \mathrm{~cm}$ and the seeding depth was 1 $\mathrm{cm}$. Immediately after sowing, the seeding grooves $(8 \mathrm{~cm})$ were mulched with peat to the depth of $0.5 \mathrm{~cm}$ and watered by sprinkling from a watering pot. Following variant 2 (Gumi-K), $200 \mathrm{~g}$ of the spruce seeds were mixed with $7.5 \mathrm{~mL}$ of the solution and left for $30 \mathrm{~min}$. Sowing was made following the same scheme as in the other variants listed above. In variant 3, the Belarusian technology was used (Zhigunov, 1998). Before sowing, the spruce seeds had been treated with the Phytozont fungicide at the rate of $1 \mathrm{ml}: 1$ liter of water for killing the infection for $18 \mathrm{~h}$. After that, the seeds were dried to the state of flowability. Before sowing was started, a nutrient substrate had been prepared from peat and soil in the ratio of $1: 1$. After thorough mixing of the nutrient substrate, lime material was added, i.e., soil deoxidizer, the Fertica complex mineral fertilizer and agroperlite. For sowing seeds of spruce, all eight cassettes, 28 cells in each, were first filled with the nutrient substrate; one cassette (the control) was filled with peat and earth in equal ratios. Three spruce seeds were sown into each cell to the depth of $0.5 \mathrm{~cm}$. Then, the seeds were watered. In the case of growing the planting material in the greenhouse conditions, it is very important to monitor the water and temperature conditions. The spruce seeds should be sown in cassettes when the temperature in the greenhouse is positive at night and +8 to $+12^{\circ} \mathrm{C}$ during the day.

Before seed germination, the entire peat layer should be wetted evenly and the humidity should be maintained before the seeds germinate (the bottom of the cassette must be constantly moist). As moisture enters the seed, the seed humidity increases from 6 to 30-40\%. During the growth stage, watering is reduced, i.e., less frequently but abundantly. On hot days, the watering is done in the morning and evening. On cloudy and cool days, watering can be skipped, but the moisture content must always be uniform. Different species require different amounts of moisture; spruce, for example, tolerates moisture fluctuations better than other species, compared to larch and pine, but suffers from excessive moisture.

During the vegetation season (May through June), all agricultural activities were performed with the crops (greenhouse ventilation, weeding, rain irrigation, spraying with biological preparations, fertilization and treatment with fungicides). 
In the open soil conditions, a plot had been first dug to the depth of one spit. After digging, the plot was leveled using a rake, i.e., large lumps of earth, grass and debris were removed. Then it was divided into four $1.5 \times 1 \mathrm{~m}$ parts (1-control, 3-with the biological products) and marks were made with a special wooden marker. Seeding was performed following the same technology described above for greenhouses.

To monitor the growth of the seedlings, the height of the plants was first measured with a ruler and adopted as the leading indicator of the yearlings' state. The survival rate was determined as the ratio of living seedlings to the number of seedlings determined after studying the field germination (Fig. 1).

\section{Statistica Analysis}

The research materials were statistically processed using the application software "Excel" Statistics. The accuracy of the research varies within 1-3\%.

Based on summer and autumn results, the main biometric indicators of spruce seedlings growth were calculated. Mathematical processing of the data was carried out by the methods of analysis of variance according to (Dospekhov, 1985). The graphs were plotted according to the method of (Ananeva, 2013) using Microsoft Office Excel 2010 and Open Office Calc (version 3.4.1).

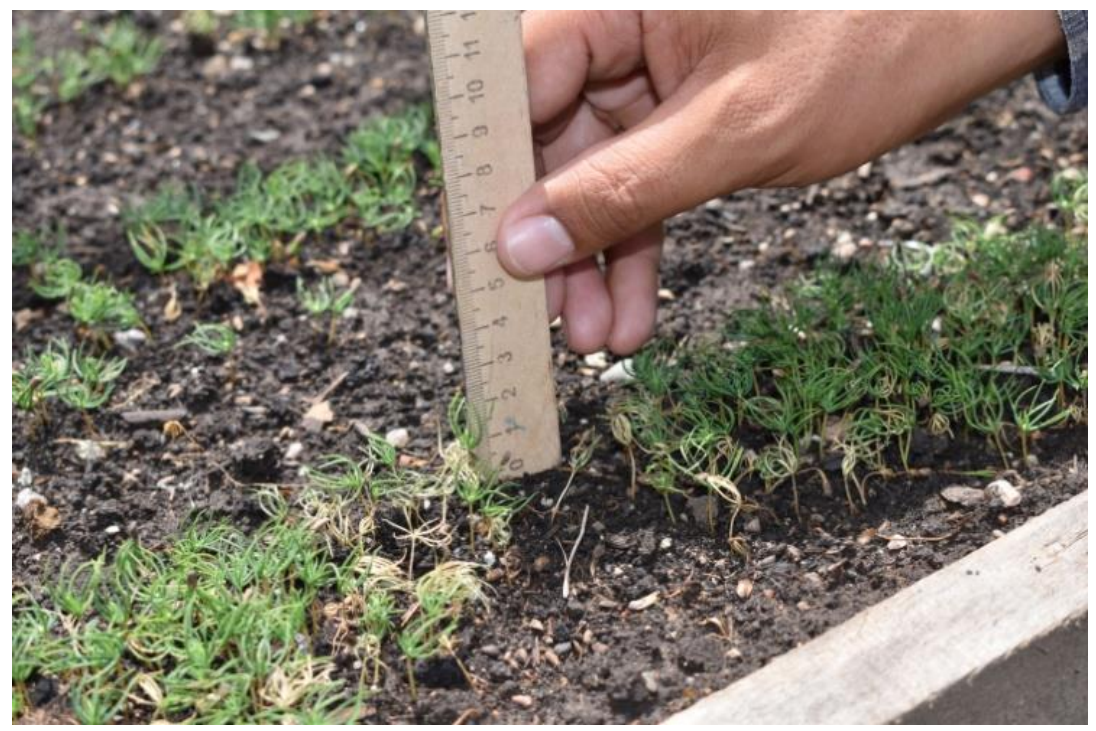

(a)

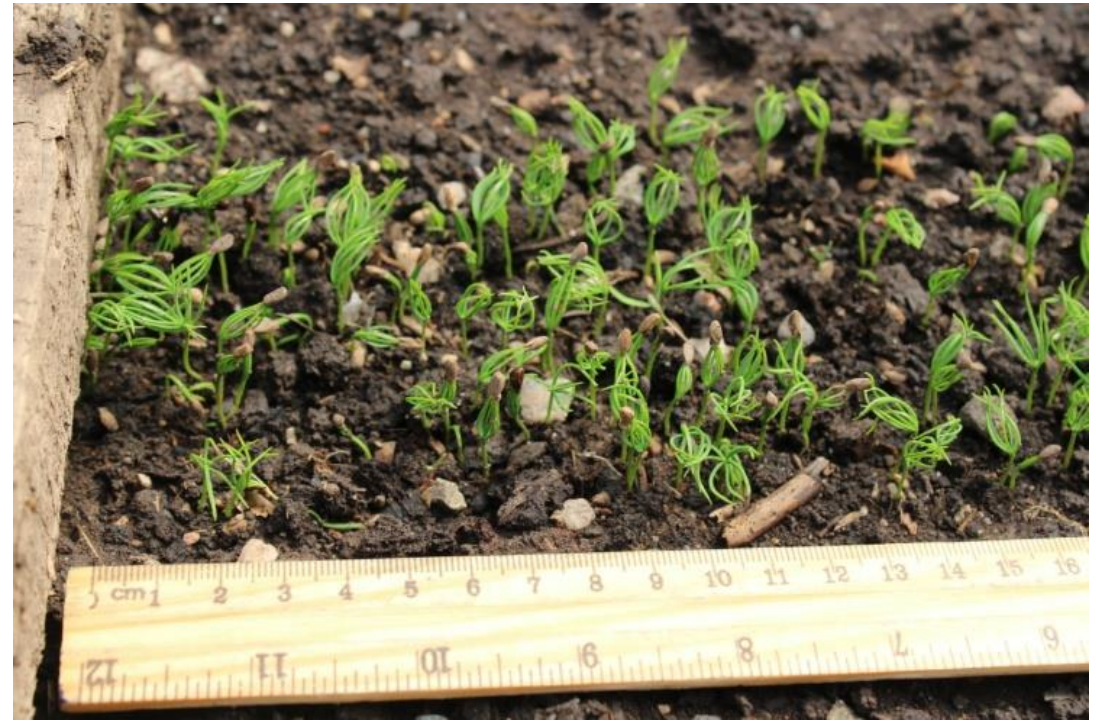

(b)

Fig. 1: The observation and measurement $(a, b)$ of the growth of Schrenk's spruce seedlings 


\section{Results}

The number of plants in the variants of the experiment was calculated in 1-meter-long accounting segments. Next, the lengths of the aboveground and underground parts of the plants were measured with a ruler, where the number of yearlings of Schrenk's spruce was no less than 35 in each variant of the experiment.

The yield of yearlings of the planting material from one meter, depending on the treatment of Schrenk's spruce in the greenhouse conditions, was determined in the autumn 2019 (Figs. 2 and 3).

The experiment shows that in the greenhouse conditions with the use of the Gumi-K stimulant, 292 yearlings of spruce were found per meter on average, while with the use of Phytobacirin, the average of 312 yearlings per meter was found, with the Belarussian cassette technology-236 pcs. The observation in the control variant showed that the average number of seedlings was 175 per one meter (Table 1).

The results of the influence of the growth stimulants in the open soil showed that in the summer, the number of yearlings of the planting material from one meter was much greater in the case of using Phytobacirin, compared to the control (137), to Gumi-K (117) and less to the Belarusian technology (61), which was within the error accuracy. During the observations in the autumn, the number of germinated seedlings increased in all variants of the experiment, i.e., the yield of seedlings from 1 meter with the use of Phytobacirin was 443, i.e., a small difference from the control (97) and Gumi-K (64) was noted, a c Belarusian technology almost equal-7 pcs. (Table 1).

The results of counting the germinated yearlings of Schrenk's spruce in the greenhouse conditions and in the open soil showed that the use of Phytobacirin for presowing treatment of the seeds and during the vegetation season for root and foliar fertilization using Deltaspray had a significant effect on the growth of the root system and the yield of Schrenk's spruce yearlings.

The observations of the yield of the planting material from one meter showed that intensive seedlings growth was observed in the spring (92-95\%) in the first 15-20 days after sowing and very few seedlings (5-8\%) appeared later (Figs. 4 and 5).

The intensive growth of the root length was noted during the vegetation season; for instance, the summer measurements in the greenhouse conditions showed a length of 3.0 to $3.9 \mathrm{~cm}$, while in the autumn, they grew from 5.3 to $6.61 \mathrm{~cm}$, i.e., the difference in the growth was evident. The use of the Belarusian technology of growing the planting material in cassettes in the greenhouse conditions did not yield a positive result due to the excessive drying of the peat and the low water-holding capacity, especially on the hottest $\left(+35\right.$ to $\left.+40^{\circ} \mathrm{C}\right)$ days of July, although during the summer measurement, they showed positive results (the stem height was $3.3 \mathrm{~cm}$ and the length of the root fibrils was $3.3 \mathrm{~cm}$ ) (Fig. 6). However, in the open soil, this technology yielded a good result both in the summer (the stem height was $4.2 \mathrm{~cm}$ and the root length was $5.0 \mathrm{~cm}$ ) and in the autumn (the stem height was $4.80 \mathrm{~cm}$ and the root length was $5.54 \mathrm{~cm}$ ), i.e., the growth of both the root system and the stem of the plants was intensive (Fig. 7).

The use of the Gumi-K preparation also showed good results in the greenhouse conditions, i.e., the summer measurements were as follows: The average height of the stem was $2.8 \mathrm{~cm}$ and the average root length was $3.6 \mathrm{~cm}$; in autumn, they reached $3.1 \mathrm{~cm}$ and $4.22 \mathrm{~cm}$, respectively. Similar results were obtained in the open soil, i.e., the average summer height of the stem was $4.4 \mathrm{~cm}$ and the average root length was $4.1 \mathrm{~cm}$, while in the autumn, the measurements were $4.95 \mathrm{~cm}$ and $5.68 \mathrm{~cm}$, respectively.

Based on the results obtained in the summer and the autumn, the main biometric growth indicators of the seedlings of Schrenk's spruce were calculated (Tables 2 and 3$)$.

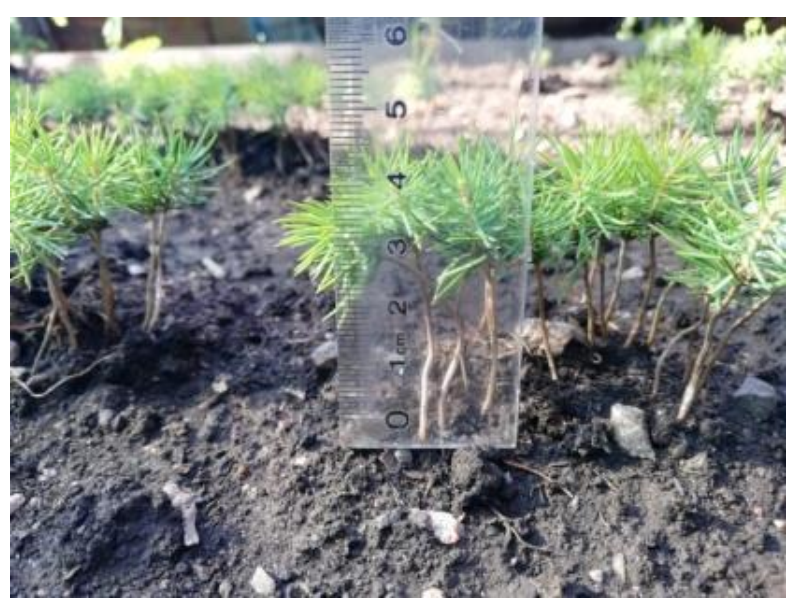

Fig. 2: Annual seedlings with the application of Gumi-K

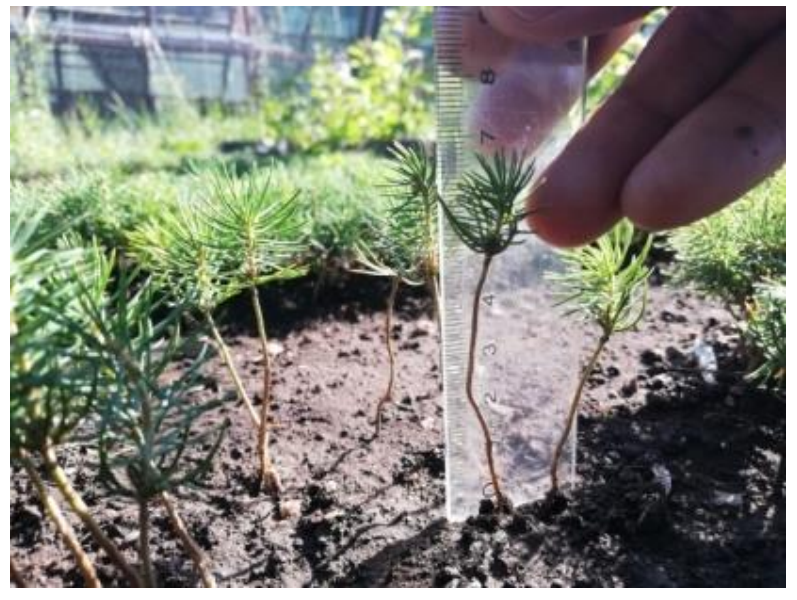

Fig. 3: Annual seedlings with the application of phytobacirin 
Zhanera Adilbayeva et al. / OnLine Journal of Biological Sciences 2021, 21 (2): 354.364 DOI: 10.3844/ojbsci.2021.354.364

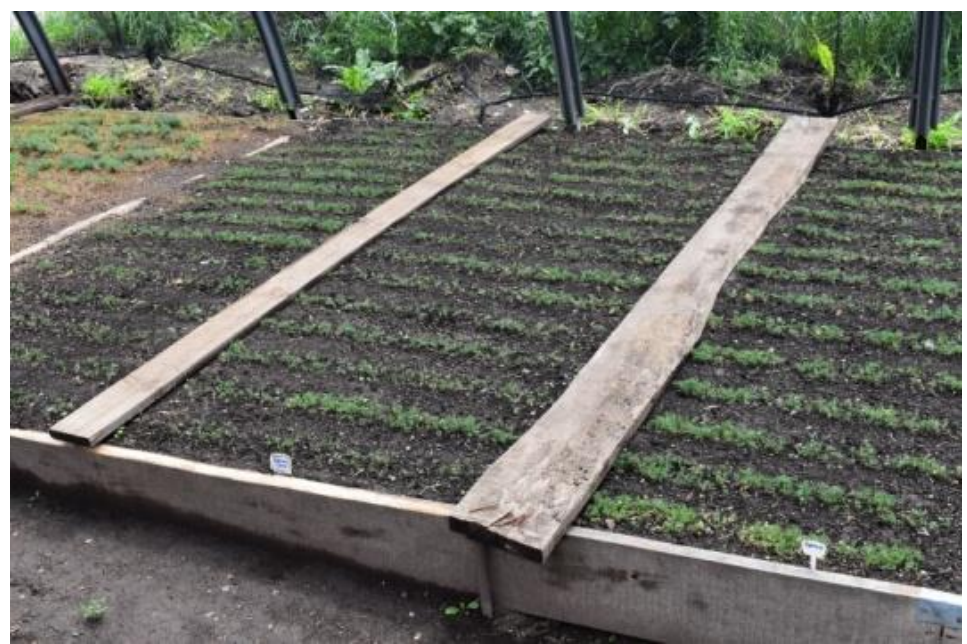

(a)

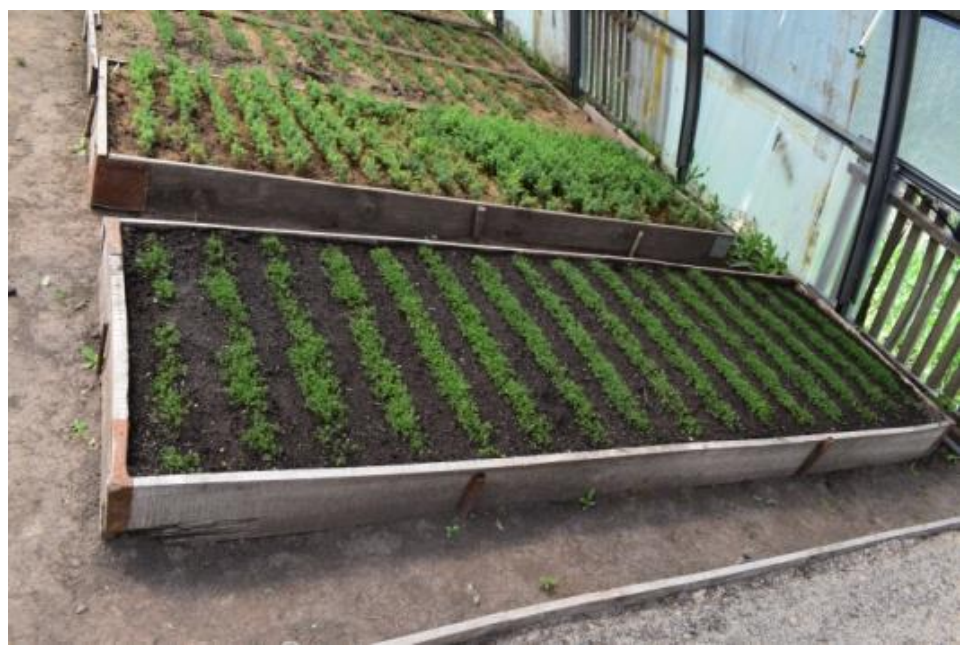

(b)

Fig. 4: General view (a, b) of annual spruce seedlings in a closed soil

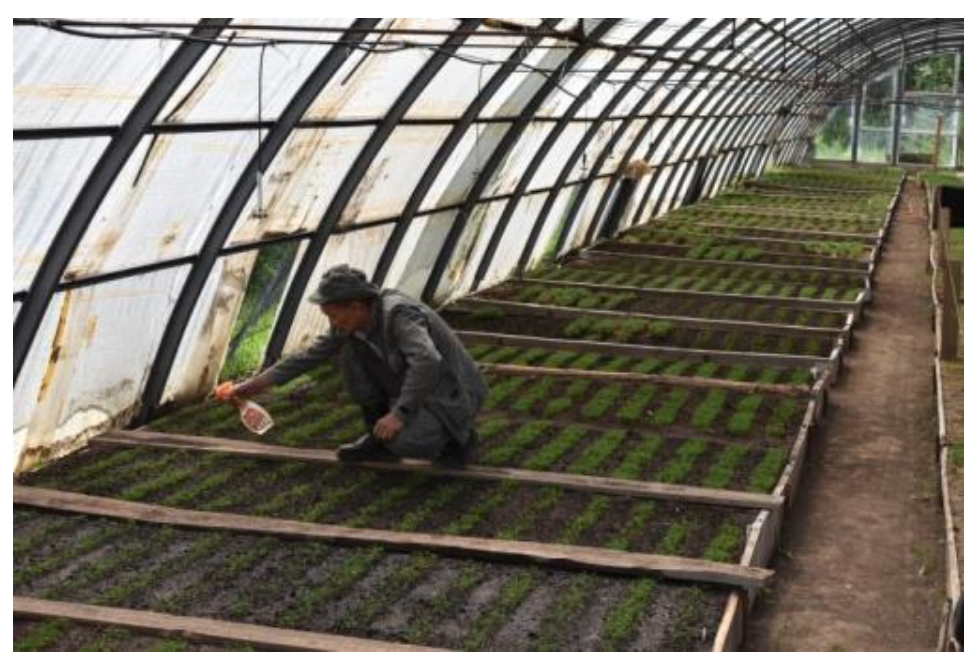

Fig. 5. Spraying with Deltaspray during the growing season 


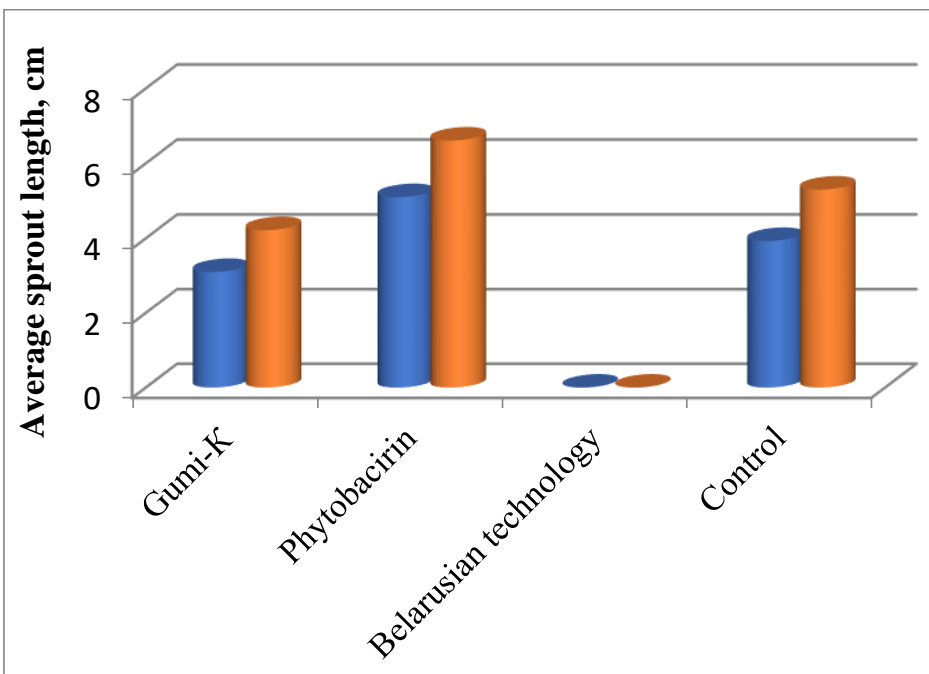

- stem height, $\mathrm{cm}$

root length, $\mathrm{cm}$

Types of growth stimulants

Fig. 6: The effect of the growth stimulants on the development of the seedlings in the greenhouse conditions Autumn, 2019

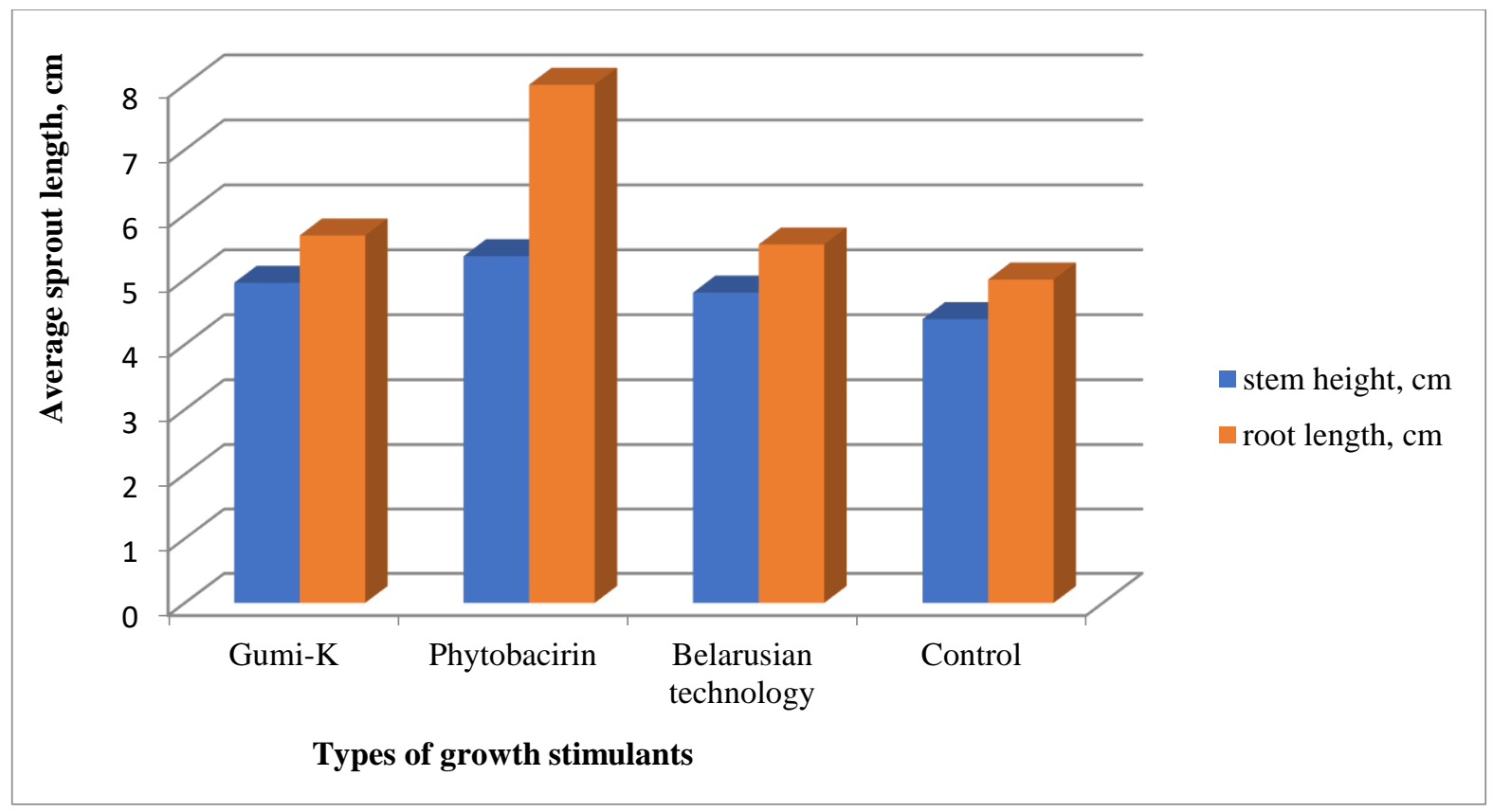

Fig. 7: The effect of the growth stimulants on the development of the seedlings in the open soil Autumn, 2019

Table 1: The impact of growth stimulants on the yield of annual seedlings per 1 1.m. Depending on the treatment of Schrenk's spruce seedlings in open soil conditions

\begin{tabular}{|c|c|c|c|c|c|c|c|c|}
\hline \multirow[b]{3}{*}{$\begin{array}{l}\text { Repetition } \\
\text { of experiments }\end{array}$} & \multicolumn{8}{|c|}{ Yield of annual seedlings from $11 \mathrm{~m}$. } \\
\hline & \multicolumn{4}{|l|}{ Summer } & \multicolumn{4}{|l|}{ Autumn } \\
\hline & Gumi-K & Phytobacirin & $\begin{array}{l}\text { The Belarusian } \\
\text { Technology } \\
\text { (sowing in cassettes) }\end{array}$ & Control & Gumi-K & Phytobacirin & $\begin{array}{l}\text { The Belarusian } \\
\text { technology (sowing } \\
\text { in cassettes) }\end{array}$ & Control \\
\hline 1 & $280 \pm 3.10$ & $292 \pm 3.14$ & $190 \pm 3.13$ & $122 \pm 2.82$ & $470 \pm 6.97$ & $490 \pm 7.90$ & $210 \pm 6.04$ & $380 \pm 1.51$ \\
\hline 2 & $300 \pm 2.96$ & $340 \pm 3.29$ & $220 \pm 2.75$ & $205 \pm 3.24$ & $280 \pm 5.91$ & $300 \pm 4.98$ & $410 \pm 5.42$ & $270 \pm 1.25$ \\
\hline $\mathrm{Cp}$. & $292 \pm 3.39$ & $312 \pm 7.15$ & $236 \pm 3.03$ & $175 \pm 2.70$ & $410 \pm 6.94$ & $443 \pm 5.89$ & $353 \pm 6.71$ & $346 \pm 1.51$ \\
\hline
\end{tabular}


Table 2: The main biometric indicators of the growth of Schrenk's spruce seedlings Summer, 2019

\begin{tabular}{|c|c|c|c|c|c|c|c|c|}
\hline \multirow[b]{3}{*}{ Indicators, $\mathrm{cm}$} & \multicolumn{8}{|c|}{ The name of the stimulant used } \\
\hline & \multicolumn{2}{|c|}{$\begin{array}{l}\text { Gumi-K } \\
\text { Growing conditions (soil) }\end{array}$} & \multicolumn{2}{|c|}{ Phytobacirin } & \multicolumn{2}{|c|}{$\begin{array}{l}\text { Belarusian technology } \\
\text { (sowing into cassettes) }\end{array}$} & \multicolumn{2}{|l|}{ Control } \\
\hline & protected & open & protected & open & protected & open & protected & open \\
\hline Stem height & $2.8 \pm 0.1$ & $4.4 \pm 0.2$ & $3.7 \pm 0.2$ & $5.0 \pm 0.1$ & $3.3 \pm 0.1$ & $4.2 \pm 0.1$ & $3.1 \pm 0.2$ & $4.1 \pm 0.1$ \\
\hline Root length & $3.6 \pm 0.3$ & $4.1 \pm 0.1$ & $3.9 \pm 0.3$ & $7.0 \pm 0.3$ & $3.3 \pm 0.1$ & $5.0 \pm 0.6$ & $3.0 \pm 0.2$ & $4.6 \pm 0.2$ \\
\hline
\end{tabular}

Table 3: The main biometric indicators of the growth of Schrenk's spruce seedlings Autumn 2019

\begin{tabular}{|c|c|c|c|c|c|c|c|c|}
\hline \multirow[b]{3}{*}{ Indicators, $\mathrm{cm}$} & \multicolumn{8}{|c|}{ The name of the stimulant used } \\
\hline & \multicolumn{2}{|c|}{$\begin{array}{l}\text { Gumi-K } \\
\text { Growing conditions (soil) }\end{array}$} & \multicolumn{2}{|c|}{ Phytobacirin } & \multicolumn{2}{|c|}{$\begin{array}{l}\text { Belarusian technology } \\
\text { (sowing into cassettes) }\end{array}$} & \multicolumn{2}{|l|}{ Control } \\
\hline & protected & open & protected & open & protected & open & protected & open \\
\hline Stem height & $3.10 \pm 0.11$ & $4.95 \pm 0.22$ & $5.1 \pm 0.15$ & $5.36 \pm 0.15$ & 0 & $4.80 \pm 0.15$ & $3.93 \pm 0.21$ & $4.39 \pm 0.12$ \\
\hline Root length & $4.22 \pm 0.18$ & $5.68 \pm 0.76$ & $6.61 \pm 0.40$ & $8.0 \pm 0.40$ & 0 & $5.54 \pm 0.60$ & $5.3 \pm 0.85$ & $5.0 \pm 0.23$ \\
\hline
\end{tabular}

The root and foliar fertilization of the seedlings with stimulants had a positive effect on their growth in the first year. In the greenhouse conditions, the stem height and the root length of the experimental plants were significantly higher than in the control, in the variants with the use of Phytobacirin and in the case of growing seedlings with enclosed root system (sowing into cassettes). Gumi-K had the least effect on the growth of Schrenk's spruce seedlings. A comparison of the open and protested soil showed that the best growth of the seedlings was noted in the open soil.

The most effective growth stimulator was Phytobacirin, which yielded better results than other variants and the control. At the same time, in the open soil, the share of the aboveground weight improved to $5.36 \mathrm{Vs}$. 4.39 in the control and the share of the roots-to 8.0 Vs. 5.0 in the control, while with Gumi-K, these values were 4.95 and $5.68 \mathrm{~cm}$ and in the case of the Belarusian cassette technology-4.8 and $5.54 \mathrm{~cm}$, respectively.

\section{Discussion}

In Russia, among the most studied preparations tested in the cultivation of coniferous seedlings are Zircon, Cresacin, Epin-Extra, Heteroauxin, Fumar, Agat-25K, Albit and Energen. Soaking the seeds of pine and spruce in a solution of growth stimulant Zircon together with a complex composition of microelements Citovit and fungicide Fundazol as a pre-sowing treatment of seeds can accelerate seed and soil germination and seedling fertilization with Zircon and Citovit helps to reduce the period of cultivation and to obtain high-quality standard material in sufficient quantity (Prokazin et al., 2013). The combination of seed treatment of conifers with Zircon and Citovit with the subsequent foliar treatment of seedlings with Cresacin, Super Humisol and Siliplant intensifies the growth processes of seedlings and increases their adaptive capacity to growing conditions (Pentelkin, 2001).
Currently, the use of growth stimulants at different stages of vegetation is being introduced into the cultivation technology of seedlings of basic forest-forming species (Egorova et al., 2017). The use of physiologically active substances as root and foliar nutrients during the cultivation of coniferous seedlings stimulates their growth and improves their quality (Shakirov, 2002). In small doses growth stimulants have a positive effect on seed germination and seedling growth of conifers and promote better development of root system and accumulation of biomass, allowing to increase the yield of planting material and reduce the cost of its cultivation. The positive effect on seedling growth is maintained for the whole period of cultivation with a single stimulant treatment (Xu et al., 2012). The foliar treatment of the Yunnan pine (Pinus yunnanensis Franch.) seedlings with auxins (IAA and IBA) had a positive effect on their growth (Pentelkina and Pentelkina, 2002). Gibberellins had a positive effect on seed germination of Cunninghamialanceolata (Lamb) Hook, while seed stratification treatment was less effective (Zhao et al., 2013). Exogenous gibberellins significantly increased seed germination of Picea smithiana (Wall. Boiss) (Mugloo et al., 2017).

Numerous studies have revealed a positive effect of growth stimulants on seed germination and seedling growth of coniferous and deciduous species (Pipinis et al., 2012; Parvin et al., 2015; Maisupova et al., 2019a).

Ustinova and Plotnikova (2006), using the Albite growth stimulant, obtained good results in planting pines in various concentrations. According to their observations, soaking pine seeds in aqueous Albite solutions of various concentrations $(0.5 \mathrm{~g} / 21,1 \mathrm{~g} / 21,1.5$ $\mathrm{g} / 21,2 \mathrm{~g} / 2$ 1) significantly influenced the growth of annual seedlings stem diameter. The control were the seeds soaked in distilled water. Three-hour exposure was used. Thus, the common pine seeds treatment with aqueous solutions of Albite allowed identifying the dosages that had caused a significant effect. 
The stimulating effect of growth regulators Zircon, Epin, Crezacin and Heteroauxin on the growth of Korean pine seedlings planted under the forest cover was shown (Ostroshenko and Akimov, 2013). Two-fold root feeding of Korean pine seedlings with the growth regulator Albit in the first year of growth has a positive effect on the growth of seedlings in all major indicators (Ostroshenko and Vatulich, 2014). Doses of preparations Zircon, Crezacin and Epin-Extra, activating germination energy and laboratory seed germination of Scots pine (Ostroshenko et al., 2015). The foliar feeding of Cajander's larch (Larix cajanderi Mayr.) seedlings with Zircon already in the first year of their growth, after transplanting to the school section of the nursery, stimulates plant growth (Ostroshenko and Zborovskii, 2009).

\section{Conclusion}

For the conditions of South-East Kazakhstan for the cultivation of planting material of Shrenk's spruce can be recommended soaking the seeds in Phytobacirin that positively influences the yield of seedlings per unit area and increases the growth of plants.

As a result of the studies, it has been found that in growing spruce seedlings, on top of the generally adopted agricultural practices that include seeds preparation for sowing and pre-sowing treatment with various growth stimulants (Gumi-K, Phytobacirin, the Belarusian cluster technology), as well as soil tillage and care for the seedlings (soil loosening, weeding, irrigation, fighting pest and diseases), additional agricultural practices include fertilization of the seedlings with solutions of mineral fertilizers, such as Korean Deltaspray.

In the first year of seedlings growing, additional fertilization is started at the moment of the formation of real needles on the seedlings and in the second year — at the beginning of the current growth gain by the seedlings and is repeated until the end of July - beginning of August. The use of complementary agricultural practices in cultivating spruce seedlings, including the root and foliar fertilization of the seedlings with the Deltaspray solution, improves the quality of planting material, i.e., increases the weight of the aboveground part and improves its ratio to the weight of fine roots. With that, the period of growing standard spruce seedlings is reduced by 1 year.

Considering the above-mentioned, it can be noted that when using growth stimulants in the open soil, one can get standard seedlings in three years, the maximum growth of above-ground mass was obtained when using the biopreparation Phytobacirin. Seedlings of Schrenk's spruce grown on the control variant have not yet reached the standard size, they need to be reared for another year. Unfortunately, when growing Schrenk's spruce seedlings in closed soil, i.e., in a greenhouse, the use of growth stimulants does not help to obtain standard seedlings within three years.

\section{Author's Contributions}

All authors equally contributed in this study.

\section{Ethics}

This article is original and contains unpublished material. The corresponding author confirms that all other authors have read and approved the manuscript and no ethical issues have been involved.

\section{References}

Ananeva, N.G. (2013). Grafiche Shoe Oformlenie Rezultatov Eksperimenta [Graphic design of the results of the experiment]. Moscow. http://genphys.phys.msu.ru/rus/lab/vtek/Graf_of_rez _eksp.pdf

Babkov, A. (2013). Agrotekhnologiya vyrashchivaniya posadochnogo materiala khvoinykh porod s zakrytoi kornevoi sistemoi [The agrotechnology of growing planting material of coniferous species with enclosed root system]. Forestry management, 9-13. http://www.rlssc.by/agro.pdf

Chilimov, A. I., Pentelkin, S. I., Pentelkina, N. V., Uskov, E. I., \& Kuznetsov,Yu. V. (1997). Novyi universal'nyi stimulyator rosta dlya vyrashchivaniya posadochnogo materiala eli obyknovennoi [A new universal growth stimulator for growing the planting material of spruce vulgaris]. Forestry,5, 40-41.

Dospekhov, B. A. (1985). Metodika polevogo opyta (s osnovami statisticheskoi obrabotki rezul'tatov issledovanii) [Methodology of field experience (with the basics of statistical processing of research results)]. Moscow: Agropromizdat. https://mf.bmstu.ru/info/faculty/lt/caf/lt1/soil_books /uchebnik9.pdf

Egorova, A. V., Chernobrovkina, N. P., \& Robonen, E. V. (2017). Vliyanie khvoinogo preparata na rost i elementnyi sostav seyantsev Pinus sylvestris L. V usloviyakh lesnogo pitomnika [Influence of coniferous preparation on the growth and elemental composition of seedlings of Pinus sylvestris L. in the conditions of a forest nursery]. Chemistry of Plant Raw Materials, 2, 171-180. http://journal.asu.ru/cw/article/view/1720

Kan, V. M., Urazbakova, U. A., \& Titov, I. N. (2017). Vliyanie zhidkogo preparata Gumi-K na produktivnost' bobov soi v serozemakh yugo-vostoka Kazakhstana [Influence of the liquid preparation Gumi-K on the productivity of soybeans in the serozems of the south-east of Kazakhstan]. Journal of Soil Science and Agrochemistry, 1, 27-34. https://cyberleninka.ru/article/n/vliyanie-zhidkogopreparata-gumi-k-na-produktivnost-bobov-soi-vserozemah-yugo-vostoka-kazahstana 
Lapa, V. V. (2011). Sistema primeneniya udobrenii [System of application of fertilizers]. Grodno. https://www.ggau.by/index.php?option=com_attach ments\&task $=$ download $\& \mathrm{id}=217$

Maisupova, B. D., Dosmanbetov, D. A., Kelgenbayev, N. S., \& Utebekova, A. D. (2019a). Sposoby uskorennogo vyrashchivaniya posadochnogo materiala (Piceaschrenkiana Fisch. et c.a. Mey.) [The methods of accelerated growing the planting material (Piceaschrenkiana Fisch. et c.a. Mey.)]. Scientificpractical magazine "Gylymzhenebilim" of the West Kazakhstan Agrarian Technical University named after Zhangir Khan, 2(55), 259-263.

Maisupova, B. D., Mambetov, B. T., Dosmanbetov, D. A., \& Utebekova, A.D. (2019b). Primenenie kornevoii vnekornevoi podkormki dlya odnoletnikh seyants eveli Shrenka [Application of root and foliar top dressing for annual seedlings of Shrenka spruce]. Gylymzhanebilim, 4(51), 76-81.

Mugloo, J. A., Mir, N. A., Khan, P. A., Perray G. N., \& Kaisar, K. N. (2017). Effect of Different Pre-Sowing Treatments on Seed Germination of Spruce (Piceasmithiana Wall. Boiss) Seeds under Temperate Conditions of Kashmir Himalayas, India. International Journal of Current Microbiology and Applied Sciences, 6(11), 3603-3612. https://www.ijcmas.com/abstractview.php?ID=5342 $\&$ vol=6-11-2017\&SNo=422

Nikolaeva, M. G., Posdova, L. M., \& Polyakova, E. N. (1987). Izuchenie vozmozhnosti uskorennogo prorashchivaniya semyan drevesnykh rastenii $\mathrm{s}$ glubokim pokoem [Studying the possibility of accelerated germination of the seeds of woody plants from deep dormancy]. Botatic Journal, 72(4), 480-488.

Novoseltseva, A. I., \& Smirnov, N. A. (1983). Spravochnik po lesnympitomnikam [Forest nurseries reference book]. Forest industry, Moscow.

Ostroshenko, V. V., \& Vatulich, D. S. (2014). Primenenie stimulyatora rosta al'bit pri vyrashchivanii seyantsev kedra koreiskogo [Application of a growth stimulant albite in the cultivation of seedlings of Korean pine]. Agroforestry and Forestry, 3, 144-147. http://www.kgau.ru/vestnik/content/2014/3.pdf

Ostroshenko, V. V. (2003). Vliyanie stimulyatorov na prizhivaemost seyantsev $\mathrm{v}$ lesnykh kulturakh [The effect of stimulants on the survival rate of seedlings in forest crops]. Proceedings of the International Forum in the problems of science, technology and education, Dec. 01-05, 2003, Akademiyanauk o Zemle, Moscow, pp: 136-138. ISBN: 5-93411-028-4.

Ostroshenko, V. V., \& Zborovskii, A. V. (2009). Vliyanie vnekornevoi podkormki tsirkonom narost sazhentsev listvennitsy Kayandera (Larix cajanderi Mayr.) [Influence of foliar top dressing with zircon on the growth of seedlings of larch Cajander (Larix cajanderi Mayr.)]. Actual problems of the forest complex, 23, 102-104.
Ostroshenko, V. V., Ostroshenko, L. Yu., Klyuchnikov, D. A., Ostroshenko, V. Yu., \& Chekushkina, T. I. (2015). Vliyanie stimulyatorov rosta na energiyu prorastaniya $\mathrm{i}$ laboratornuyu vskhozhest' semyan sosny obyknovennoi (Pinus sylvestris L.) [Influence of growth stimulants on germination energy and laboratory germination of seeds of Scots pine (Pinus sylvestris L.)]. Proceedings of SamNTs RAN, 17(6), 242-248.

http://www.ssc.smr.ru/media/journals/izvestia/2015/ 2015_6_242_247.pdf

Ostroshenko, V. V., \& Akimov, R. Yu. (2013). Vliyanie stimulyatorov narost sazhentsev sosny kedrovoi koreiskoi (Pinus koraiensis Siebold et Zucc.) pod pologom khvoino-shirokolistvennykh lesov. VestnikKrasGAU, 7, 89-93. http://www.kgau.ru/vestnik/content/2013/7.13.pdf

Parvin, P., Khezri, M., Tavasolian, I., \& Hosseini, H. (2015). The effect of gibberellic acid and chilling stratification on seed germination of Eastern black walnut (Juglans nigra L.). Journal of Nut, 6, 67-76. https://www.sid.ir/en/journal/ViewPaper.aspx?id=45 5243

Pentelkin, S. K. (2001). Primenenie Agata-25K v lesnomkhozyaistve [Application of Agata-25K in forestry]. Forestry, 2, 41-43.

Pentelkina, N. V., \& Pentelkina, Yu. S. (2002). Stimuliruyushchee deistvie tsirkona narost seyantsev khvoinykh introdutsentov [Stimulating effect of zircon on the growth of seedlings of coniferous introduced plants]. Vestnik MGUL - Lesnoivestnik, 2, 24-29.

Pentelkina, Yu. S. (2003). Vliyanie stimulyatorov na vskhozhest' semyan i rost seyantsev khvoinykh vidov [Effect of stimulants on germination of seeds and growth of seedlings of coniferous species]. Ph.D. dissertation, MGUL, Moscow, Russia, 2003. https://www.dissercat.com/content/vliyaniestimulyatorov-na-vskhozhest-semyan-i-rostseyantsev-khvoinykh-vidov

Pipinis, E., Milios, E., Mavrokordopoulou, O., Gkanatsiou, C. H., Aslanidou, M., \& Smiris, P. (2012). Effect of Pretreatments on Seed Germination of (Prunus mahaleb L.). Notulae Botanicae Horti Agrobotanic, 40, 183-189. https://doi.org/10.15835/nbha4027887

Prokazin, N. E., Lobanova, E. N., Pentelkina, N. V., Kazakov, V. I., Ivanyusheva, G. I., Sakhnov, V. V., Chukarina, A. V., \&Bagaev, S.S. (2013). Vliyanie biostimulyatorov i mikroudobrenii na rost seyantsev khvoinykh porod [Influence of biostimulants and microfertilizers on the growth of coniferous seedlings]. Forestry information, 2, 9-15. http://lhi.vniilm.ru/PDF/2013/2/LHI2013_02_03_Le snye_kultury.pdf

Rodin, A. R. (2002). Lesnyekultury [Forest crops]. MGUL, Moscow.ISBN:5-8135-0103-7. 
Rubtsov, V. I. (2009). Lesnye pitomniki [Forest nurseries]. Prisveshenie, Moscow.

Shakirov, F. R. (2002). Primenenie krezatsina pri vyrashchivanii seyantsev sosny obyknovennoi (Pinus sylvestris L.) v usloviyakh Bashkirskogo Predural'ya [The use of crezacin in the cultivation of seedlings of scots pine (Pinus sylvestris L.) in the conditions of the Bashkir Urals]. PhD. Thesis, BashGU, Ufa. https://www.dissercat.com/content/primeneniekrezatsina-pri-vyrashchivanii-seyantsev-sosnyobyknovennoi-pinus-sylvestris-l-v-u

Smirnova, I. E., Koishibaev, M. K., Saubenova, M. G., Kuznetsova, T. V., \& Sadanov, A. K. (2012) Biologicheskii sposob stimulyatsii rosta i zashchity sel'skokhozyaistvennykh rastenii ot fitopatogennykh gribov [Intensive technologies of growing planting material and reforestation]. Patent RK №24974.

Titov, I. N., \& Kan, V. M. (2015). Standart of KazNIIPA «Biopreparat zhidkii guminovyi «Gumi-K» [biological liquid humic product "Gumi-K"], ST 4201910-01-TOO-01-2015.

Ustinova, T. S., \& Plotnikova, G. P. (2006). Primenenie stimulyatorov pri vyrashchivanii khvoinykh porod [The use of stimulants in growing conifers]. Current Problems of the Forest Complex, 13, 249-250.
Volkovich, A. P., \& Nosnikov, V. V. (2015). Intensivnye tekhnologii vyrashchivaniya posadochnogo materiala i lesovosstanovleniya. BGTU, Minsk. https://www.belstu.by/Portals/0/userfiles/44/files/int ensivTehnolog/Intensivnie-tehnologii.pdf

Xu, Y., Zhang, Y., Li, Y., Li, G., Liu, D., Zhao, M., \&Cai, N. (2012). Growth Promotion of Yunnan Pine Early Seedlings in Response to Foliar Application of IAA and IBA. International Journal of Molecular Sciences, 13(5), 6507-6520. https://pubmed.ncbi.nlm.nih.gov/22754380/

Zhao, G., Zhong, T., \& Zhao, G. (2013). Influence of exogenous IAA and GA on seed germination, vigor and their endogenous levels in Cunninghamia lanceolate. Scandinavian Journal of Forest Research, 28(6), 511-517. https://doi.org/10.1080/02827581.2013.783099

Zhigunov, A. B. (1998). Teoriya i praktika vyrashchivaniya posadochnogo materiala $\mathrm{s}$ zakrytoi kornevoi sistemoi dlya lesovosstanovleniya [Theory and practice of growing planting material with a closed root system for reforestation]. $\mathrm{PhD}$ thesis. https://www.dissercat.com/content/teoriya-ipraktika-vyrashchivaniya-posadochnogomateriala-s-zakrytoi-kornevoi-sistemoi-dlya- 